【論 文】

UDC : $697.94: 697.328$

\title{
水蓄熱式空調システムにおける機器挙動之 エネルギー消費に関する研究
}

正会員 櫻 井

翰*

\section{1.はじめに}

熱源機器容量の軽减, 機器のバックアップ対策あるい はエネルギー供給側からの消費平準化に応える等の理由 で，蓄熱式空調システムが採用されるケースが増えつつ ある。水蓄熱による開放回路方式のものが最も一般的で あるが，同方式はエネルギー消費の視点からは全負荷運 転による熱源機器効率の向上などの利点がある反面, 搬 送動力の増大や槽からの伝熱損失など蓄熱に伴なう種々 のロスが指摘されている。研究分野では，システムのエ ネルギー消費を直接扱ったものより, 槽内水の温度応答 之混合流れ機構の関係, 蓄熱有効水域, 蓄熱性能あるい は槽からの伝熱損失など，むしろ蓄熱槽自体の特性に着 目した内容の報告が多い。槽内水の温度応答特性につい ては文献1）などに多くの実験結果が示されているが, さらに文献 2) では槽の有効容積率（P 值）とともに, 水温応答特性から水の混合流れ特性 $\mathrm{M}$ 值が定義されてい る。また直接蓄熱槽の性能を表す指標として, 蓄熱慒効 率 ${ }^{31}$ ・蓄熱効率 $\left.{ }^{4}\right|^{(}$蓄熱能率 ${ }^{51}$ 等をそれぞれ定義し議論を 展開しているが，ここで言う蓄熱槽の性能とはその第一 義すなわち, 一次側, 二次側温度のある制約のもとに, できるだけ小さな容積にいかに大きな熱量を蓄え得るか を評価する尺度と考えられる。こうした観点から筆者ら も実槽における投入・排出温度加ら槽の熱保持率を新た に定義し，実測值からその值を求めることを試みてい る6。しかしシステム全体としてとらえるならば，蓄熱 槽も構成一要素であり, システムとしての動的評価, あ るいはエネルギー消費視点からの評価が重要である。筆 者は前述の蓄熱槽の混合流れ特性あるいは性能指標が同 時に，機器挙動ならびにエネルギー消費にも大きくかか わると考えているが，これまでの報告例では，長期間に わたってシステムとして稼動した場合にそれらが定量的 によ゙う影響するかあるいは効果を示すかについてまでは 言及されていない。機器挙動ならびにエネルギー消費に 対しては, 蓄熱槽自体の特性とあいまって, 熱源機器発 停の制御方法や二次側消費特性などシステムにかかわる 種々の要因が交絡的に影響を及ぼすと考えられるが，こ

* 清水建設株式会社技術研究所 主任研究員 (1988 年 5 月 31 日原槁受理, 1989 年 4 月 18 日採用決定)
こで槽内の混合流れ特性および伝熱損失と機器挙動・エ ネルギー消費との定性的なかかわりについて推測してみ る。一般に熱源機器の発停は槽内水温によって制御され る場合が多いが，その水温分布は槽への還水温度・入出 水量とともに，混合流れ特性によって決まる。したがっ て, 槽の混合流れ特性は熱源機器の運転時間を左右する。 この運転時間は冷却塔ファンや一次ポンプ等補機動力の 消費に直接影響を与える。また吸い込み温度は熱源機器 の運転負荷率すなわち，電力あるいは然料消費効率にか かわってくる。二次 (消費) 側で見ると, 汲出水温は空 調機器のコイル流量, したがって二次ポンプの搬送動力 に影響を与える。一方槽からの伝熱損失についても水温 を介して, 汲出流量・発停等機器挙動を左右するため, 伝熱による熱源動力あるいは燃料増のみによどまらず, エネルギー消費全般に影響を及ぼすと考えられる。この ように槽特性は水温を介して機器挙動に大きくかかわっ ており，また非蓄熱式システムと違い熱源製造と消費時 間帯とにずれがあることから，熱収支計算のみによる方 法からは機器の挙動状態が把握できない。したがって蓄 熱式空調システムではまづ, 水温分布および機器挙動を 的確にとらえ，その結果としてエネルギー消費量を求め る過程が必要と考える。

以上の観点から, 本報告では槽内水の混合流れ機構と, 槽からの伝熱損失に的を絞り, それらが機器の挙動なら びにエネルギー消費にどう影響するかを解析的に研究す るものである。まず，現実の蓄熱式空調システムとして 想定される影響因子をできるだけ多く組み入れ, 機器挙 動を模擬し，また槽内では押しだし流れ領域と混合流れ 領域が混在する場合の水温分布をいかにして表現するか を考え, 機器シミュレーション過程を電算プログラム化 した。次に標準的なモデルシステムを設計し，同プログ ラムを適用することによって, 水温分布の状態を含め機 器挙動並びにエネルギー消費構造がどうなっているか, またそれらに対して混合流れ特性・伝熱損失が定量的に どうかかわっているかを検討した。

\section{2. 解析方法}

非蓄熱システムへの適用を対象として作成された図一 1 のような空調機器シミュレーション・プログラム゙を 


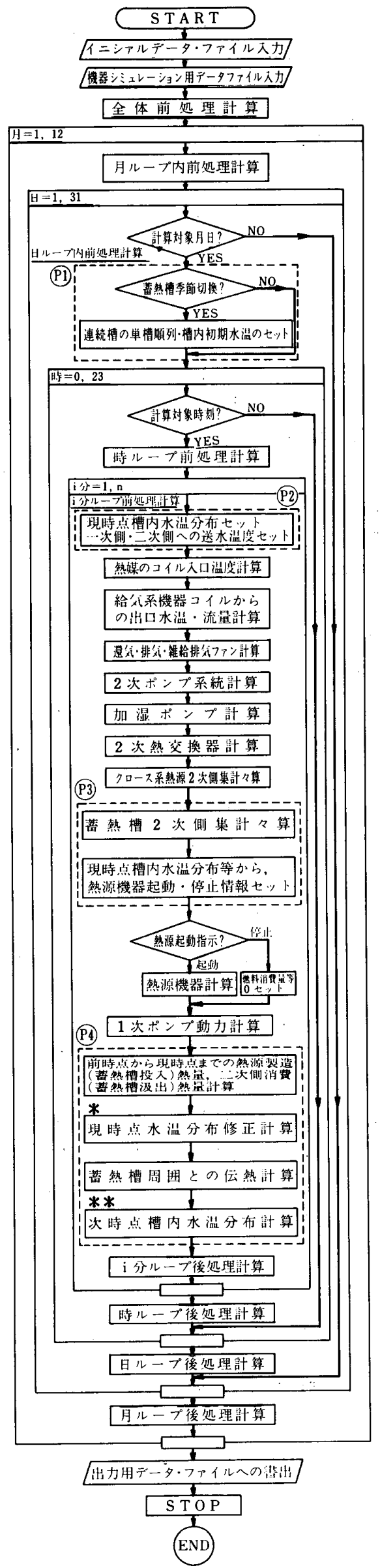

図一1機器シミュレーション部 フローチャート
基本プログラム として用い，そ れに図中(P)か ら(84)印で示す 蓄熱式空調シス テム固有の解析 過程を組み込ん だ。蓄熱槽内の 水温変動等水挙 動に与える影響 が特に大きい槽 への入出流量 . 還水温度は空調 機器コイルの特 性解析から各機 器ごとに流量 ・ 出口温度を得て 計算してい $3^{8)}$ 。建物側熱 負荷については HASP 相当の 動的熱負荷計算 プログラムによ り，あらかじめ 年間各時刻値を 求めておき機器 シミュレーショ ン部への入力と した。

2.1 前進差 分型の近似方解 法

非蓄熱式シス テムでは, 前時 点の影響を無視 し，近似的に系 全体を擬定常扱

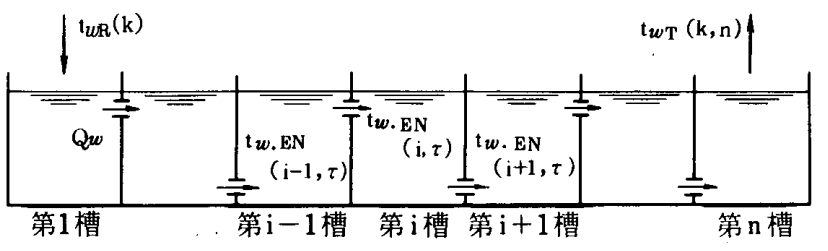

図-2 連結槽形蓄熱槽各点の水温と流量

いとすることができるが，蓄熱槽では一般に槽内水容積 に比べ流量が小さく，水挙動を解く上での時定数が大き くなるため非定常計算を必要とする。システム全体では 関数の数も多くまた複雑な連係から，解析解はもとより 解の発散を防ぐのに有効な時間後退差分型の数值解法に ついても適用が困雑であり，前進差分型の計算を基本と せざるを得ない。しかし，系全体は時間差分型の計算構 造をとるが，機器系については蓄熱槽内の水温および槽 への流出入水量をパラメータとすれば，非蓄熱式システ ムと同様に擬定常計算とすれば良く, 非定常計算は蓄熱 槽内の (水温分布) 解析に限定できる。すなわち（1） 式に示すように，その時点 ( $k$ 時点) の水温分布をもと に擬定常計算から, 機器系より槽への還り水温を求め, (2) 式が示す時間前進差分型の計算によって次時点の 水温を得る逐次解法とすることができる。

（擬定常計算） $t_{w R}(k)=f_{1}\left(t_{w \tau}(k, 1), t_{w \tau}(k, n)\right.$,

$$
\left.Q_{w \tau}(k), \cdots\right)
$$

(非定常計算) $t_{w T}(k+1, i)=f_{2}\left(\Delta \tau, t_{w T}(k, i), t_{w R}(k)\right.$,

$$
\left.Q_{w \tau}(k), \cdots\right) \cdots \cdots \cdots(2)
$$

ここに, $f_{1}, f_{2}$ : 関数, $t_{w R}(k): k$ 時点における蓄熱槽 への還水々温, $t_{w T}(k, i), t_{w T}(k+1, i): k$ (現) 時点, $k+1$ (次) 時点における第 $i$ 槽々内水温望1)， $Q_{w T}(k): k$ 時点における蓄熱槽への出入水量を表す（図一2参照）。 ここに, $f_{1}, f_{2}$ : 関数, $t_{w R}(k): k$ 時点における蓄熱槽 への還水々温, $t_{w T}(k, i), t_{w T}(k+1, i): k$ (現) 時点, $k+1$ (次) 時点における第 $i$ 槽々内水温 ${ }^{* 11}, Q_{w T}(k): k$ 時点における蓄熱槽への出入水量を表す（図一2 参照）。

（2）式の具体的な方法は後節 2.3 で述べる。

\section{2 系の熱収支整合}

蓄熱システムでは一次側と二次側機器の稼動時間帯に

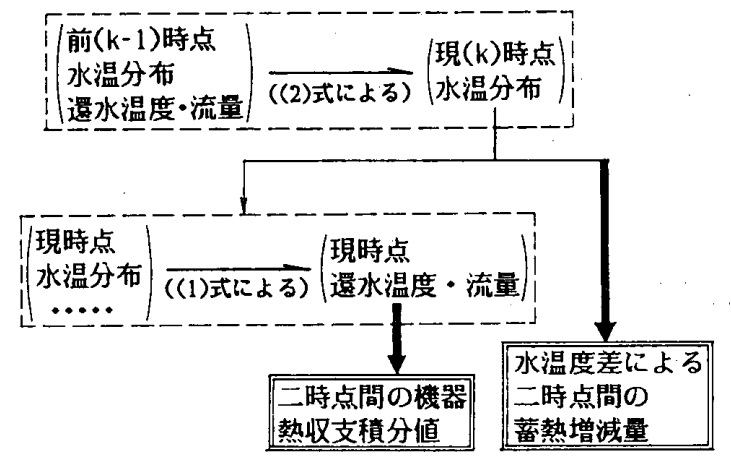

図一3 前・現時点間の蓄熱増減量と機器熱収支

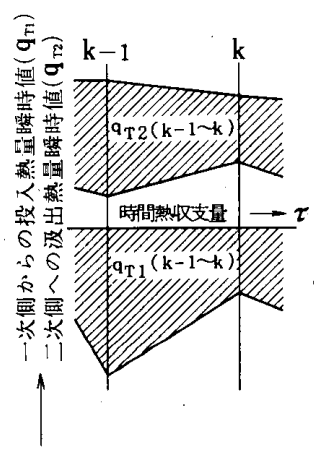

図一4 機器熱収支量の積分 


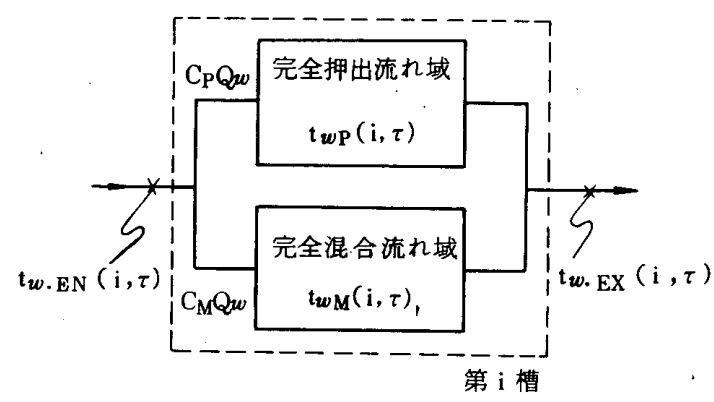

図一5 単槽内の混合流れ解析モデル

ずれがあるが，各機器挙動は槽内水温分布を介して拘束 され，また機器側からの槽の熱収支はすべて水温分布と して反映される。したがって，水温分布と機器からの熱 収支量とに長期間にわたる整合性が保たれないと，熱源 製造熱量, 二次側消費熱量の期間值あるいは蓄熱槽残量 等の間に不整合が生ずることになる。図一 3 に示すごと く, 前述の (2) 式からは（前時点において）現時点の 槽内水温分布が得られるが，それをもとに前・現時点間 の水温差が示す蓄熱増減量と, 図一4のごとく機器側に 対する槽の熱収支積分量とが求められる。本来これら双 方の量は同じであるべきだが，この計算過程のみでは双 方を一致させる拘束性は何等与えていない。そこで各時 点において, 双方の值を一致させるべく, 各槽に共通の 一定值 $\Delta t_{w}$ で以て, $t_{w \tau}(k, i)$ を修正するようにした ${ }^{i 22)}$ 。 $\Delta t_{w}$ は次式を満たす。

$$
\begin{aligned}
& q_{\tau_{1}}(k-1 \sim k)+q_{\tau_{2}}(k-1-k) \\
& \quad=\sum V_{i}\left[\left\{t_{w \tau}(k, i)+\Delta t_{w}\right\}-t_{w \tau}(k-1, i)\right]
\end{aligned}
$$

ここに, $q_{T_{1}}(k-1 \sim k): k-1$ (前) 時点から, $k$ (現) 時点までの間の蓄熱槽に対する一次側からの投入熱量, $q_{T_{2}}(k-1 \sim k)$ : 同じく二次側への汲み出熱量, $V_{i}$ : 第 $i$ 槽の水量

(3) 式から $\Delta t_{w}$ は,

$$
\begin{aligned}
\Delta t_{w}= & \left\{q_{T_{1}}(k-1-k)-q_{T_{2}}(k-1, k)\right\} / 1000 V_{T} \\
& -\sum V_{i} \cdot\left\{t_{w \tau}(k, i)-t_{w T}(k-1, i)\right\} / V_{T}
\end{aligned}
$$

ここに, $V_{T}$ : 蓄熱槽の合計水量

よって各槽の修正後水温 $t_{w T}^{\prime}(k, i)$ は,

$$
t_{w r}^{\prime}(k, i)=t_{w r}(k, i)+\Delta t_{w}
$$

ここで修正分 $\Delta t_{w}$ の值は小さいほざ系全体の解析精度 が向上するが，これは実行時の時分割間隔之容量の関係 によって左右される。このため水温修正量の実行全期間 における出現頻度分布状態をチェックしている。図一1 では, (14)過程の $(* *$ 印) 部分から (前時点で) 得ら れた現時点分布值を（*印）部分で修正するようにし てある。

\section{3 槽内水温分布}

前記 (2) 式の過程は現時点值を初期値として次時点
すなわち差分の時分割間隔 $\Delta \tau$ 後の水温分布を求めるこ とになるが，次のような蓄熱槽モデルを設定しその数值 解によっている。モデルは図一5に示すように完全押し 出し流れ之完全混合流れの領域がある比率で存在し, 槽 内水温はそれらの混合水温として与えられるすなわち $\tau$ 時間後における第 $i$ 槽の出口水温 $t_{w . E x}(i, \tau)$ は, 次式 より求められると考えた。

$$
t_{w . E x}(i, \tau)=C_{P} \cdot t_{w P}(i, \tau)+\left(1-C_{P}\right) \cdot t_{w M}(i, \tau)
$$

ここに, $C_{P}$ : 完全押し出し流れ域の比率 ${ }^{* 3)}, t_{w P}(i, \tau)$ : 第 $i$ 槽完全押し出し流れ域の平均水温, $t_{w M}(i, \tau)$ : 第 $i$ 槽完全混合流れ域の平均水温

第 $i-1$ 槽から $i$ 槽へ， $\tau$ 時間後に流入する水温が，0 $\tau$ の範囲で次式に示す如く,

$$
t_{w . E N}(i, \tau)=a_{0}(i) \cdot \tau^{2}+a_{1}(i) \cdot \tau+a_{2}(i) .
$$

$\tau$ の二次関数として近似すれば， $(6)$ 式の $t_{w p}(i, \tau)$, $t_{w m}(i, \tau)$ は以下のようにして求めることができる。各 単槽における一回還水時間を $\tau_{N i}[\mathrm{~h}]$ として,

（1） $t_{w \mathrm{P}}(i, \tau)$ は, 槽への入出熱量差値 $\Delta q$ が,

（イ） $\tau \leqq \tau_{N i}($ 一回還水以内）では,

$$
\begin{aligned}
& \Delta q=\int_{0}^{\tau}\left\{t_{w . E N}(i, \tau) \cdot 1000 C_{P} V_{i} N_{i}\right\} d \tau \\
& -1000 C_{P} V_{i} N_{i} \tau t_{w \tau}(k, i) \\
& =1000 \dot{C}_{P} V_{i} N_{i}\left(a_{0}(i) \cdot \tau^{3} / 3+a_{1}(i) \cdot \tau^{2} / 2\right. \\
& \left.+a_{2}(i) \cdot \tau-t_{w \tau}(k, i) \tau\right\}
\end{aligned}
$$

（口） $\tau>\tau_{N i}$ (一回還水以上) の場合はすべてが, $\left(\tau-\tau_{N i}\right) \sim \tau$ の間に流入してくる部分と考え $\tau$,

$$
\begin{aligned}
& \Delta q=\int_{\tau-\tau_{N i}}^{\tau}\left\{t_{w . E N}(i, \tau) \cdot 1000 C_{P} V_{i} N_{i}\right\} d \tau \\
& =1000 C_{P} V_{i} N_{i} \mid a_{0}(i) \cdot \tau^{3} / 3+a_{1}(i) \cdot \tau^{2} / 2+a_{2}(i) \cdot \tau \\
& -a_{0}(i) \cdot\left(\tau-\tau_{N_{i}}\right)^{3} / 3-a_{1}(i) \cdot\left(\tau-\tau_{N_{i}}\right)^{2} / 2 \\
& \left.-a_{2}(i) \cdot\left(\tau-\tau_{N_{l}}\right)\right\}
\end{aligned}
$$

ここに, $N_{i}$ : 第 $i$ 槽の還水回数 $[/ \mathrm{h}], V_{i}$ : 同水量 $\left[\mathrm{m}^{3}\right]$ となるから， $t_{w P}(i, \tau)$ は次式 (10) によって得られる。

$$
t_{w P}(i, \tau)=t_{w \tau}(k, i)+\Delta q / 1000 C_{P} V_{i}
$$

(2) 完全混合流れ領域では, 各槽で次の方程式が成 り立つ。

$$
\begin{aligned}
& 1000\left(1-C_{P}\right) V_{i} N_{i}\left\{a_{0}(i) \cdot \tau^{2}+a_{1}(i) \cdot \tau+a_{2}(i)-t\right\} d \tau \\
& =1000 V_{i} d t
\end{aligned}
$$

これを $t$ について解いて,

$$
\begin{aligned}
t_{w M}(i, \tau)= & a_{0}(i) \cdot\left(\tau^{2}-2 \tau / N_{i}+2 / N_{i}^{2}\right) \\
& +a_{1}(i) \cdot\left(\tau-1 / N_{i}\right)+a_{2}(i)+\left\{t_{w \tau}(k, i)\right. \\
& \left.-2 a_{0}(i) / N_{i}^{2}+a_{1}(i) / N_{i}-a_{2}(i)\right\} e^{-N_{i} \tau}
\end{aligned}
$$

一方, 次の槽に対する $(7)$ 式の係数, $a_{0}(i+1), a_{1}(i$ $+1), a_{2}(i+1)$ は, 上式の $\tau=0,0.5 \Delta \tau, \Delta \tau$ の三時 
点の值から得られる注4。 以上の方法により次時点 の第 $i$ 槽水温 $t_{w r}(k+1$, i) は, $t_{w . E X}(i, \Delta \tau)$ と して得られる。

3. モデル建物と空気 調和システム

3.1 建物モデル

建物は東京に位置し， 基準階，立面をそれぞれ 図一6, 図一7に示すよ うな延床面積が約 9000 $\mathbf{m}^{2}$ の事務所建築を設定 した。建物熱負荷にかか わる外皮構造 · 照明等の 条件並びに空調運転形態 を表一1，表一2に示す。

\section{2 空気調和システム}

上記建物に設置すべき蓄熱式空調システムについて は，できるだけ一般的で標準的なモデルとなるように考 慮し, システムの方式並びに各機器の容量・機器性能・ 制御設定值等を設定した。空調方式は, 空気系を各階工 アハンドリングユニットとファンコイルユニットの併用 方式とし，冷温熱源には空冷ヒートポンプを採用した。 配管系統全体の概略を図一8に示す。機器容量の設定に 際しては一般的な設計方法に習ったが，安全率による笠 上げ (型番増) なよ゙はせず，計算結果のままもしくは極 めて近い機器を選定した。空調機器のコイルについては 二方弁による流量制御方式を採用し，また入口温度は冷 水側を $5^{\circ} \mathrm{C}$, 温水側は $45^{\circ} \mathrm{C}$, 各温度差 $5^{\circ} \mathrm{C}$ とし列数 容量の軽減，(3)熱源のバックアップ等各設置意図にした を計算したがその差が大きかったため冷・温水ダブルコ イルとした。一方，蓄熱式空調システムでは，(1)熱源の 大部分を夜間電力で賄おうとする完全蓄熱, (2)熱源機器 がって，蓄熱槽と熱源機器容量との間には自ずと一定の 関係があるが，ここでは，(1)並びに(2)の場合を想定して モデルを設定した。蓄熱槽は(1)の場合をべースとして， 建物全体の冷・暖房負荷の年間最大值出現日における日 積算負荷をすべて蓄熱槽で賄うための所要蓄熱容積と建
築基礎部の状況から，図一 12 に示すような水深 $2.3 \mathrm{~m}$, 最大容積が $812 \mathrm{~m}^{3}$ の複槽型の連結槽を考えた。また(2) については, 最大負荷に対する熱源機器容量の軽減率 $50 \%$ として, 不足所要分を蓄熱量とすることを考え, 上記蓄熱槽をバルブ切り替えによって所要容積 $447 \mathrm{~m}^{3}$ として使えるように配慮した。前述のシステム設置意図 (1)の場合の熱源機器容量は, 22 翌朝 8 時の 10 時間で 満杯になるように能力選定した。また設置意図(1), (2)の 場合とも深夜電力利用の観点から 22 時に起動する深夜 運転を主体とし，昼間時は初槽水温での不足感知起動お よび最終槽水温による満杯停止を制御する発停管理方式 としだ。また熱源機器出口温度と蓄熱槽からの吸い込み 温度を一定值に制御し, 後者については（初槽と最終槽 双方から汲み出し：三方弁制御により行う方式とした。 熱源機器の発停優先条件と二次側への利用限界となる槽 内水温を表一 3 に示す。以上のごとく設定したシステム について；一次回りの全動力を深夜電力で賄おうとする 場合をモデルシステム(1), また熱源機器容量の $50 \%$ 軽 減意図で設定した方をモデルシステム(2)とする。主要機 器の仕様をまとめて表一 4 に, 二次側可変速ポンプなら びに熱源機器の部分負荷入力特性を図一-9, 10, 11 に示 す。
表一1 建物外皮構造亡熱負荷設定条件

\begin{tabular}{|c|c|}
\hline 外壁 & 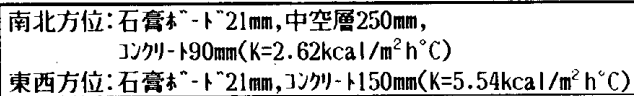 \\
\hline 屋根 & 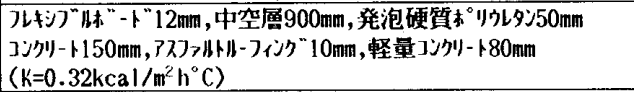 \\
\hline 空 & 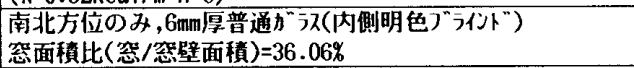 \\
\hline 在室人員 & $0.2 人 / \mathrm{m}^{2}$ \\
\hline 照明密度 & $15 \mathrm{w} / \mathrm{m}^{2}$ \\
\hline 外気量 & $25 m^{3} / h \cdot$ 人(9時〜) \\
\hline
\end{tabular}

表一2 空調運転条件

\begin{tabular}{|c|c|c|c|}
\hline 3 & 冷房運転 & 暖穷運転 & 換気運転 (熱源非製造期間) \\
\hline 稼 動 期 間 & $\begin{array}{l}\text { 5月16日 } \\
\sim 10 \text { 月15日 }\end{array}$ & $\begin{array}{l}\text { 12月 } 1 \text { 日 } \\
\sim 3 \text { 月 } 31 \text { 日 }\end{array}$ & $\begin{array}{c}\text { 4月 } 1 \text { 日 } \sim 5 \text { 月15日 } \\
10 \text { 月16日 } \sim 11 \text { 月 } 30 \text { 日 } \\
\end{array}$ \\
\hline 空調運転時間 & & $\begin{array}{l}\text { 平 日 } \\
\text { 土曜日 } \\
\text { 日曜日 } \\
\end{array}$ & $\begin{array}{l}\text { 時 } 18 \text { 時 } \\
\text { 時 } 13 \text { 時 } \\
\text { 停止 }\end{array}$ \\
\hline 外気取入れ停止時間 & & 平·土曜日 & 8 時 9 時 \\
\hline $\begin{array}{l}\text { 室内温度設定値 } \\
\text { 室内湿度設定值 }\end{array}$ & $26^{\circ} \mathrm{C}$ & $20^{\circ} \mathrm{C}$ & \\
\hline
\end{tabular}




\section{4. 熱負荷}

建物全体の室内と外気の各䫓・潜熱負荷を合計した全 熱負荷の年間値は，冷房・暖房側それぞれ $262.8 \mathrm{Gcal}$, $225.5 \mathrm{Gcal}$ 併せて $488.3 \mathrm{Gcal}$ であった。延床面積当た りの值の最大值とその出現日は冷房側が $59.7 \mathrm{kcal} / \mathrm{m}^{2} \mathrm{~h}$ (8月 14 日 16 時)，暖房負荷は $80.4 \mathrm{kcal} / \mathrm{m}^{2} \mathrm{~h}$ ( 1 月 5 日 9 時）であった。図一13 は全熱負荷の最大值に対す る負荷率 $5 \%$ 刻みで集計した出現頻度と累積頻度分布 を示すが冷房負荷はほぼ均等に分布しているが，暖房負 荷の方は負荷率 $60 \%$ 以下の負荷が全体の $90 \%$ を占め 低負荷となっている。また年間を通しての延床面積当た り時間平均值は冷房・暖房側それぞれ $24.6 \mathrm{kcal} / \mathrm{m}^{2} \mathrm{~h}$, $28.1 \mathrm{kcal} / \mathrm{m}^{2} \mathrm{~h}$ であった。

\section{5. システムの挙動とエネルギー消費構造}

適用すべき前記プログラム構造並びに解析方法の妥当 性を, 機器挙動によって確認し, そのエネルギー消費構 造を把握するためまづ，3. のモデルシステム(1)よっ
て時分割間隔 $\Delta \tau$ を 0.5 時間，また各単槽は完全押し出 し流れと混合流れ領域がそれぞれ $50 \%$ を占める( $C_{P}=$ $0.5 ）$ 槽であるとして年間シミュレーションを実行した (これをケース@とする)星。その結果について述べる。

\section{1 除去熱量}

熱負荷に対して要求される空調機器コイルレベルでの 除去あるいは加熱々量（以下併せて単に要求除去熱量と 呼ぶ）の年間值は泠熱側が $227.3 \mathrm{Gcal}$, 温熱側が 204.5 Gcal，実除去熱量の方は冷・温熱側それぞれ 176.0 Gcal, 204.5 Gcal であった。冷熱側の要求と実除去熱 量の差は，コイルが顕熱制御により除湿側は成行きとな るためである。

\section{2 槽内水温と機器挙動}

冷・暖房最盛時の 2 月， 8 月と中間期の 5 月の各 10 日間を選び，蓄熱槽内水温・空調機器コイルからの還水 平均温度・還水 (二次ポンプ) 流量の合計並びに熱源製 造熱量の各時刻変動を図一14；15，16に示す。図から

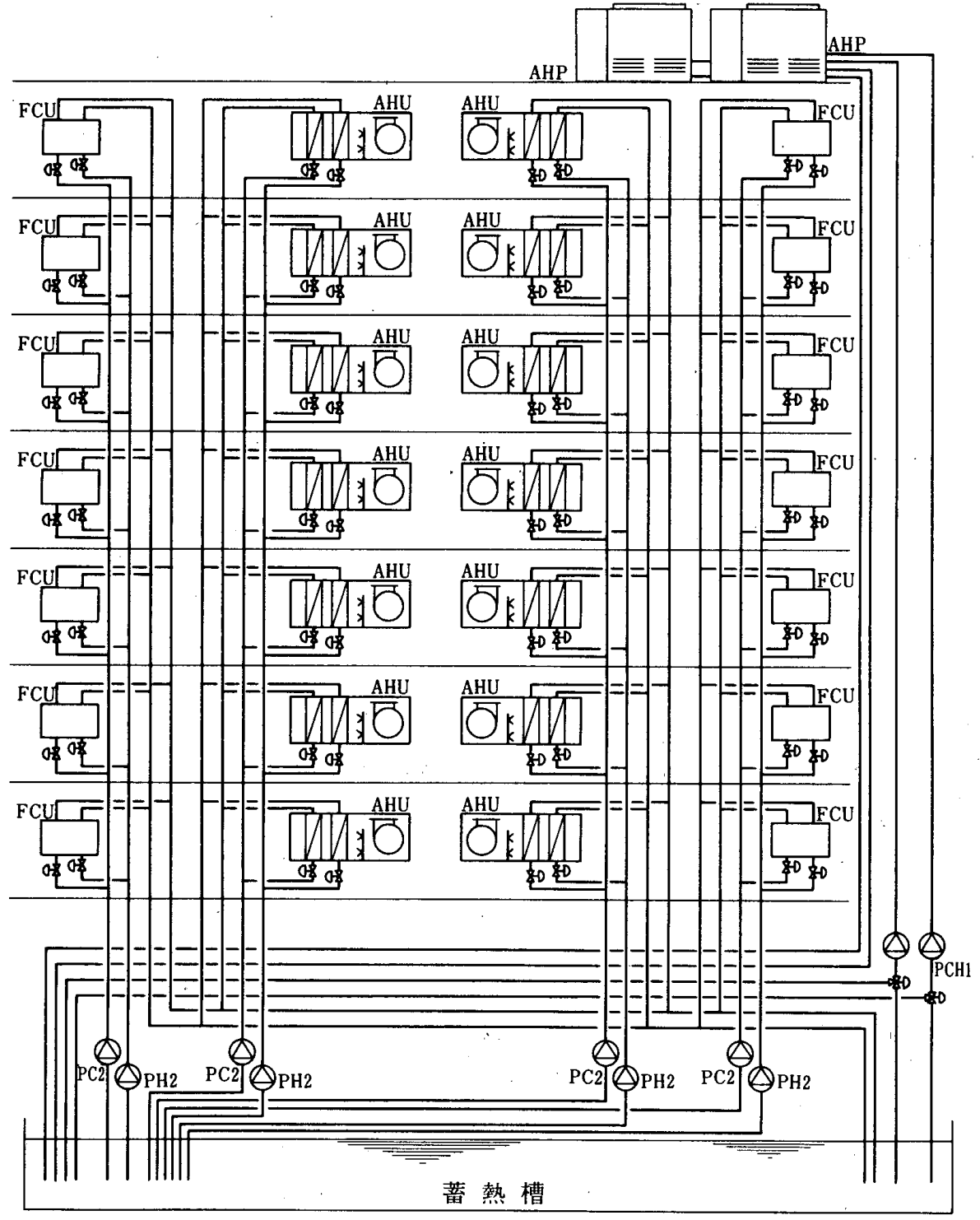

図一8 モデル空調システム

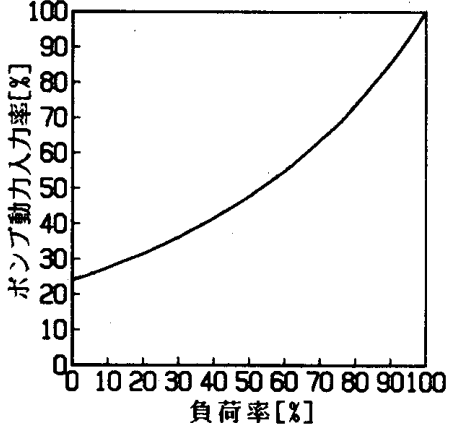

図一9 二次ポンプ入力特性
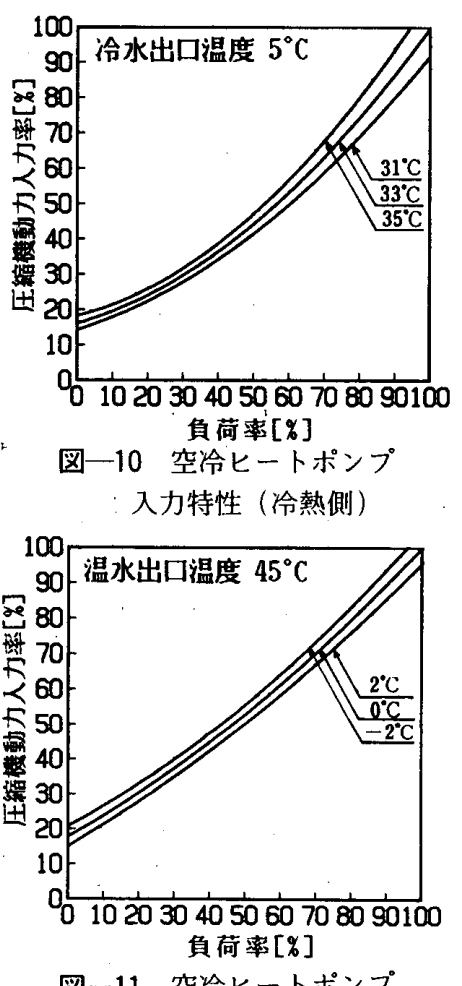

図一11空冷ヒートポンプ 入力特性（温熱側） 


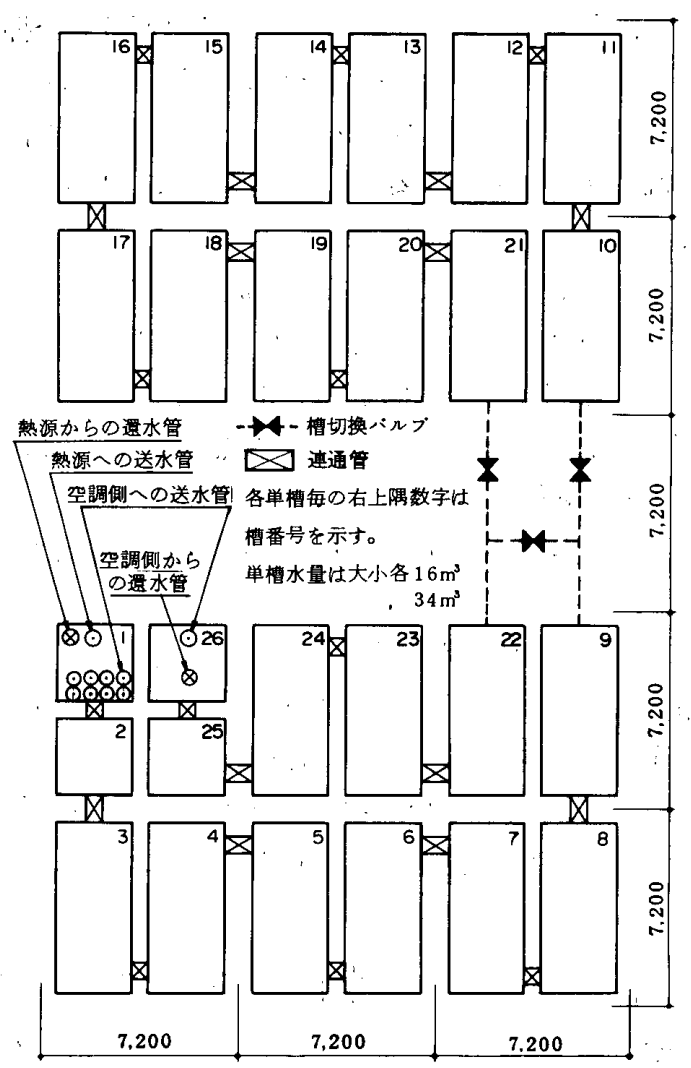

表-4 機器仕様

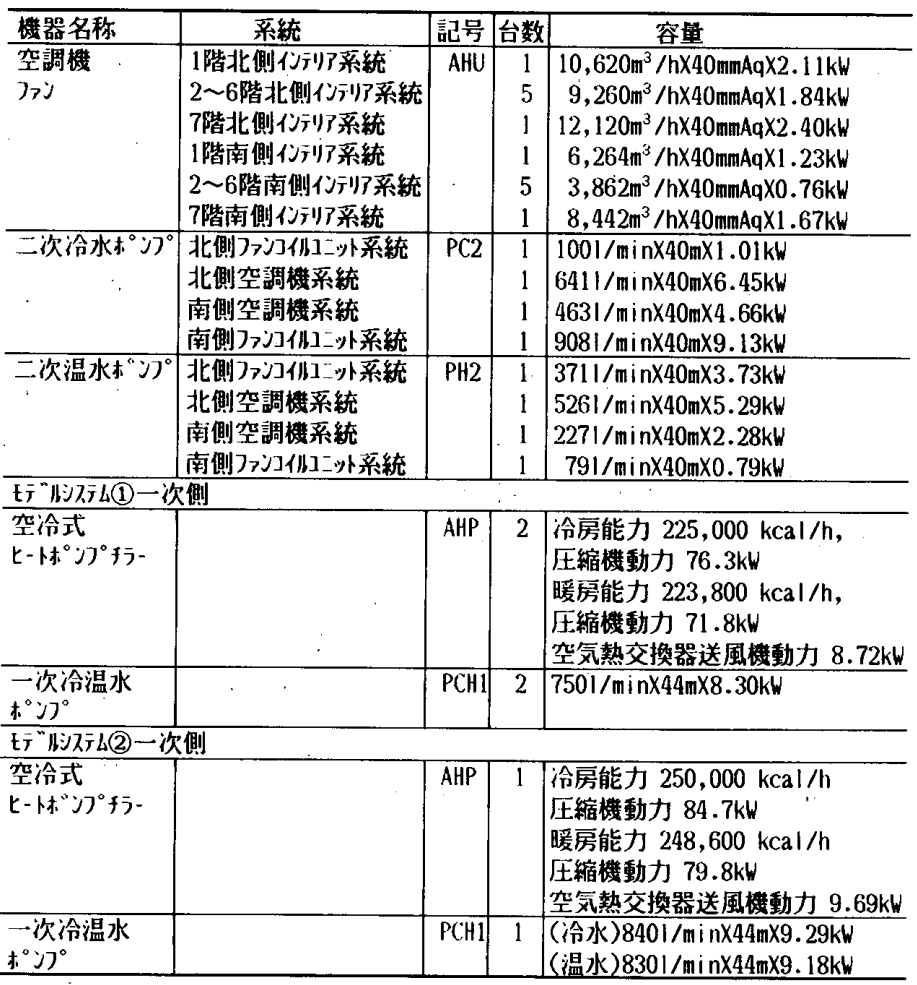

図一12 蓄熱槽モデル平面図

表一3 熱源機器発停の槽内水温条件

\begin{tabular}{|c|c|c|c|}
\hline \multicolumn{2}{|c|}{ 期間 单槽 } & 初槽水温状態 & 最終槽水温状態 \\
\hline \multirow{2}{*}{ 冷房期 } & 爇源発停 & $9^{\circ} \mathrm{C}$ 以上で起動 & $5.3^{\circ} \mathrm{C}$ 以下で停止 \\
\hline & 空調利用 & $10^{\circ} \mathrm{C}$ 以下で利用 & \\
\hline \multirow{2}{*}{ 暖房期 } & 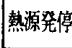 & $41^{\circ} \mathrm{C}$ 以下で起動 & $44.7^{\circ} \mathrm{C}$ 以上で停止 \\
\hline & 空澗利用 & $40^{\circ} \mathrm{C}$ 以上で利用 & \\
\hline
\end{tabular}

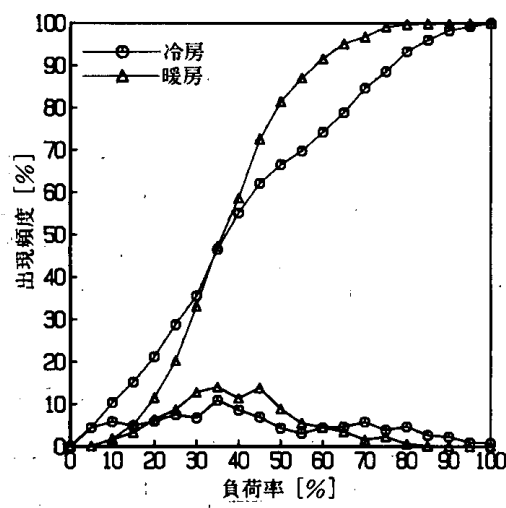

図一13 建物全熱負荷出現頻度

間のうち 22 時一翌朝 8 時まで の夜間が 1286 時間と全体の 99 $\%$ を占めており, 極力深夜電 力を利用するとした蓄熱槽設置 ならびに熱源容量の設定意図に 沿う稼動状況であったと言え る。熱源の製造熱量は冷熱側が $186.8 \mathrm{Gcal}$, 温熱側 が 234.8 Gcal で併せて $421.6 \mathrm{Gcal}$ と なっているが，前述の実除去熱 量との差は, 冷・暖房期間終了

はまづ，初槽（新蓄熱側から見て第 1 槽）・最終槽（同 第 26 槽）内水温亡熱源機器発停時点とのかかわりが確 かめられるが，熱源発停のサイクルを見ると毎日定時 (22 時) に起動し; 冷・暖房最盛期には, 吸い込み側・ 出口温度共に制御設定值に維持される全負荷運転時間が 長く，またいずれも 8 時前に停止することが多く, 停止 前には冷熱側は吸い込み側制御水温以下に下降し, 温熱 側は上昇するため制御不可となるいわゆる部分負荷運転 状態となっている。中間期には大半が部分負荷運転と なっている。また初槽の水温はほぼ一定值に維持されて いるが, 比較的最終槽に近い槽では, 空調機器コイルか らの還り水温が時々刻々変動するため, 水温が乱れる(分 布が逆転する）現象が見られる。

\section{3 熱源機器の期間稼動状況}

各熱量収支・熱源運転時間ならびにエネルギー消費量 の年間値をまとめて表一 5 に示す。まづ, 熱源の運転時
日（温熱側が 4 月 15 日と 12 月 31 日；冷熱側が 10 月 15日).における蓄熱残量の合計值とそれぞれ対応して 认る。一次ポンプ・補機動力消費量へも影響する熱源の 運転時間を見ると, 年間1278時間であり,この内冷熱 側が 607 時間, 温熱側が 671 時間を占めている。また, 温熱側の全負荷運転時間に占める割合は $66 \%$ である が，冷熱側の方は $50 \%$ とやや低くすなわち，反対に部 分負荷運転時間が多くなっていることを示している。こ れは暖房期間が 12 月から 3 月の 4 力月で, 比較的高負 荷月で占められるのに対し，冷房側は $5 \cdot 6 \cdot 10$ 月の比 較的低負荷となる月が含まれ，図一15（5月）のごとく 部分負荷運転時間帯が多くなるためである。

5.4 期間エネルギー消費

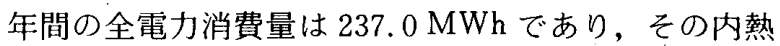
源 (圧縮機) 動力は $113.3 \mathrm{MWh}(47.8 \%)$, 一次ポンプ・ 熱源補機動力の合計は $48.1 \mathrm{MWh}(20.3 \%)$ ，二次側搬 


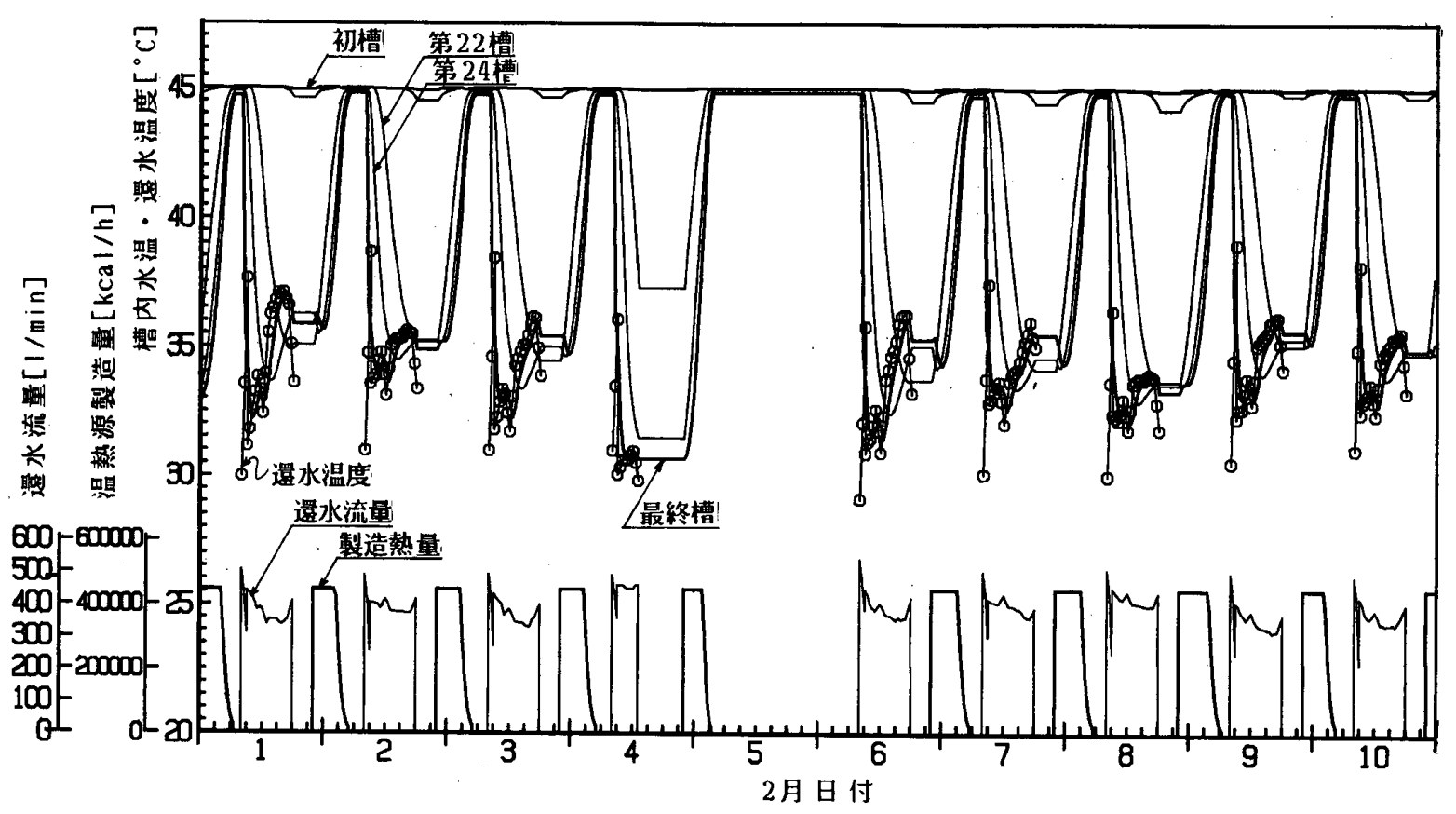

図一14 蓄熱槽内水温変動と機器挙動 $(2$ 月)

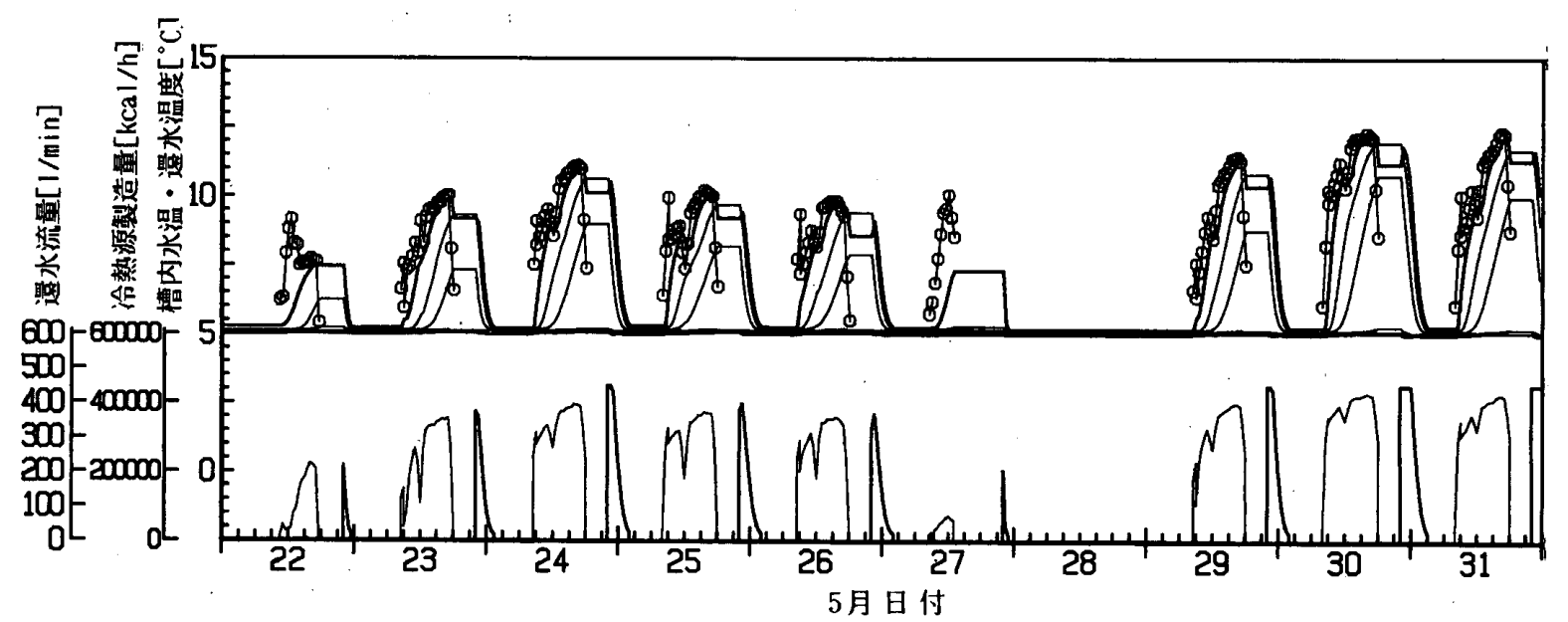

図一15 蓄熱槽内水温変動と機器挙動（5 月）

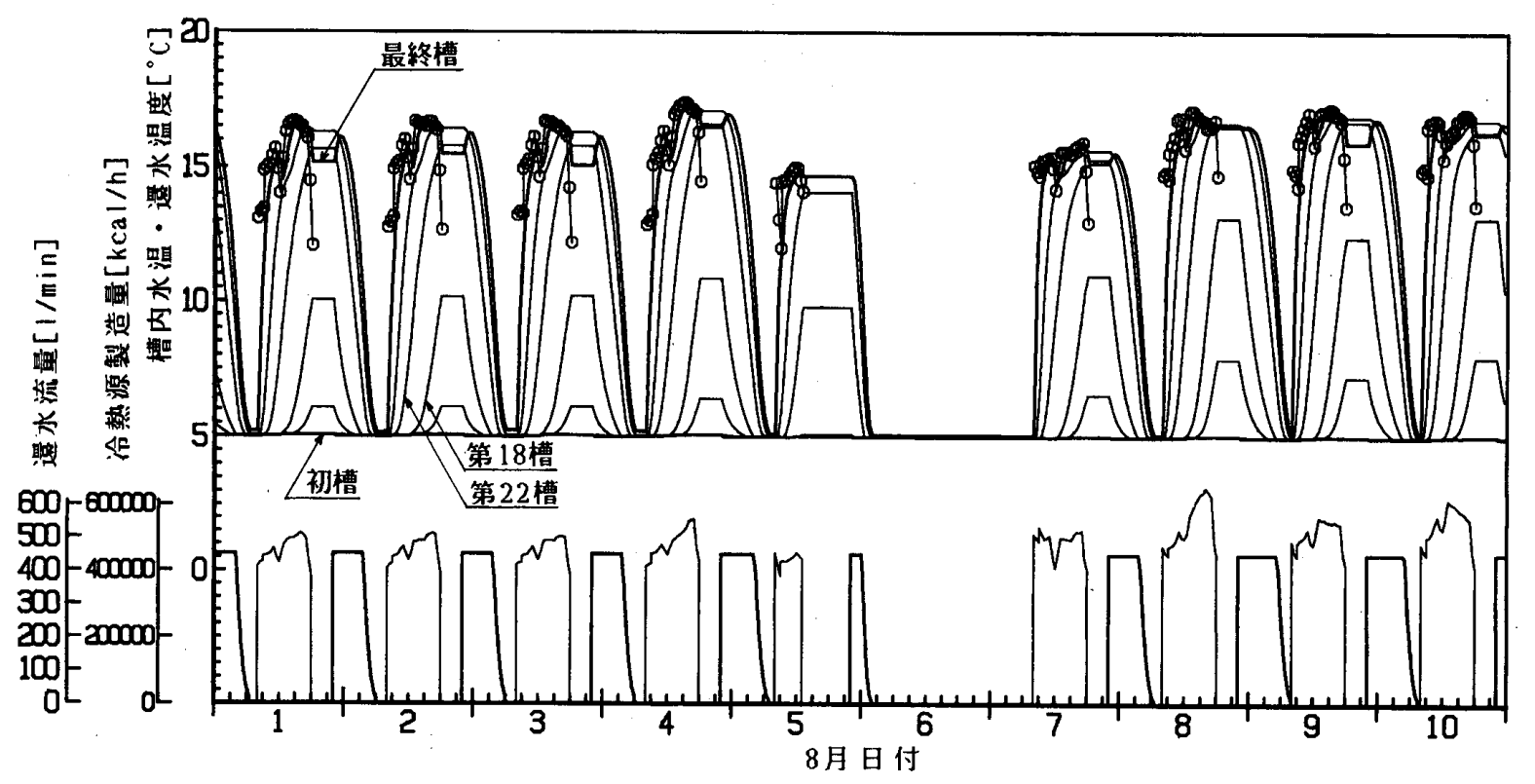

図一16 蓄熱槽内水温変動之機器挙動 (8月) 
表 5 ケース@の熱源運転時間とエネルギー消費年間值

\begin{tabular}{|c|c|c|c|c|}
\hline & 单位 & 冷熱侧 & 温熱侧 & 全体 \\
\hline 建物全熱負荷 & Gcal & 262.8 & 225.5 & 488.3 \\
\hline \multicolumn{5}{|l|}{ 空調機了价、“川 } \\
\hline 所要除去熱量 & Gcal & 227.3 & 204.5 & 431.8 \\
\hline 実除去熱量 & Gcal & 176.0 & 204.5 & 380.5 \\
\hline \multicolumn{5}{|l|}{ 熱源 } \\
\hline 製造熱量 & Gcal & 186.8 & 234.8 & 421.6 \\
\hline 全運転時間 & $\mathrm{h}$ & 607.0 & 671.3 & 1278.3 \\
\hline 夜間運転時間 & h & 607.0 & 661.8 & 1268.8 \\
\hline 部分負荷運転時間 & $\mathrm{h}$ & 300.8 & 228.8 & 529.5 \\
\hline \multicolumn{5}{|l|}{ 熱源 } \\
\hline 圧箔機動力 & MWh & 44.70 & 68.62 & 113.32 \\
\hline 空気熱交換器動力 & MWh & 12.66 & 9.63 & 22.29 \\
\hline 一次样り”動力 & MWh & 11.78 & 14.04 & 25.82 \\
\hline 空調器フフコ動力合計 & MWh & 38.63 & 26.38 & 65.01 \\
\hline 三次末゚ク動力 & MWh & 6.64 & 3.93 & 10.57 \\
\hline 全動力合計 & MWh & 114.41 & 122.60 & 237.01 \\
\hline 二次I被”－換算值 & Gcal & 280.3 & 300.4 & 580.7 \\
\hline $\begin{array}{l}\text { 二次I神件" - 換算 } \\
\text { 消費係数 }\end{array}$ & & 1.07 & 1.33 & 1.19 \\
\hline
\end{tabular}

送動力の合計は75.6 MWh (31.9\%) を占め, 熱源補 機之併せた全搬送動力は熱源圧縮機動力を上回ってい る。また電力消費量の熱源と搬送動力とに分けた一次エ ネルギー換算值と, それらの建物全体熱負荷に対する工 ネルギー消費係数を，各月について求めた結果を表一6 に示す。年間の一次エネルギー換算值は熱源側が 277.6 Gcal，搬送側は $303.0 \mathrm{Gcal}$, 全体で $580.6 \mathrm{Gcal}$, 同じ くその消費係数については, 熱源側が 0.57 , 搬送側は 0.62 , 併せて 1.19 となった。 5 ，10月の中間期の消費 係数がそれぞれ 1.69，1.61 と大きな值を示しているが, これは定風量システムであり，空調機ファン動力が他の 月と変わらず, 全動力に占める割合が大きいことによる (5，10月の搬送側消費係数がそれぞれ $1.16,1.34$ と 特に大きい)。

\section{6. 槽内の混合流れ特性による影響}

槽内の混合流れ特性が機器エネルギー消費量へ及ぼす 影響を調べるために，3.で述べたモデルシステム(1), (2)の各々について, 各単槽が完全押しだし流れ領域 100 $\%\left(C_{P}=1.0\right.$, 以下この場合を “押流” と略称する $), 0 \%$ $\left(C_{P}=0.0\right.$, 以下, “間流” と略称する $)$ とした場合と, 同一容積でも分割槽数を減らすことによって，蓄熱槽全 体としてはより完全混合流れ現象に近くなると想定され るケース $\left(C_{P}=0.0\right.$, 以下, “混流”と略称する）につ いて(b)〜(g)の合計 6 ケースを設定した。まづ，図一17 はモデルジステム(1)から“押流”（ケース(b) 亡・“混流”

表-6 一次エネルギー消費係数の月別値

\begin{tabular}{|c|c|c|c|c|c|c|c|c|c|c|c|c|c|}
\hline 月 & 1 & 2 & 3 & 4 & 5 & 6 & 7 & 8 & 9 & 10 & 11 & 12 & \\
\hline 全熱負荷 & 64.1 & 65.9 & 46.4 & 0.0 & 17.9 & 36.2 & 66.0 & 84. & 45.7 & 12.8 & 0.0 & 48. & 488. \\
\hline & & 1.2 & 29.6 & 12.8 & 20.7 & 24.1 & 29.9 & & 4.8 & 7.1 & 12.8 & & \\
\hline 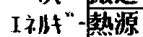 & & & 9.3 & 0.0 & 9.5 & & 26.4 & & 18.8 & 3.5 & 0.0 & & \\
\hline 奥算檤全1 & & & 3.9 & 12.8 & 30.2 & & 56.3 & & 43.6 & 20.6 & 12.8 & 5.8 & 580.6 \\
\hline 肖貫 般 & & 0.47 & 0.64 & & 1.16 & 0.67 & 0.45 & 0.43 & 0.54 & 1.34 & & 0.72 & 0.62 \\
\hline & & & \begin{tabular}{|l|}
0.6 \\
\end{tabular} & & 0.53 & & 0. & & 0. & 0.27 & & 1.04 & 0.57 \\
\hline & & 1 & & & 1.69 & .93 & 0.85 & & 0.95 & .61 & & 1.7 & 1.19 \\
\hline
\end{tabular}

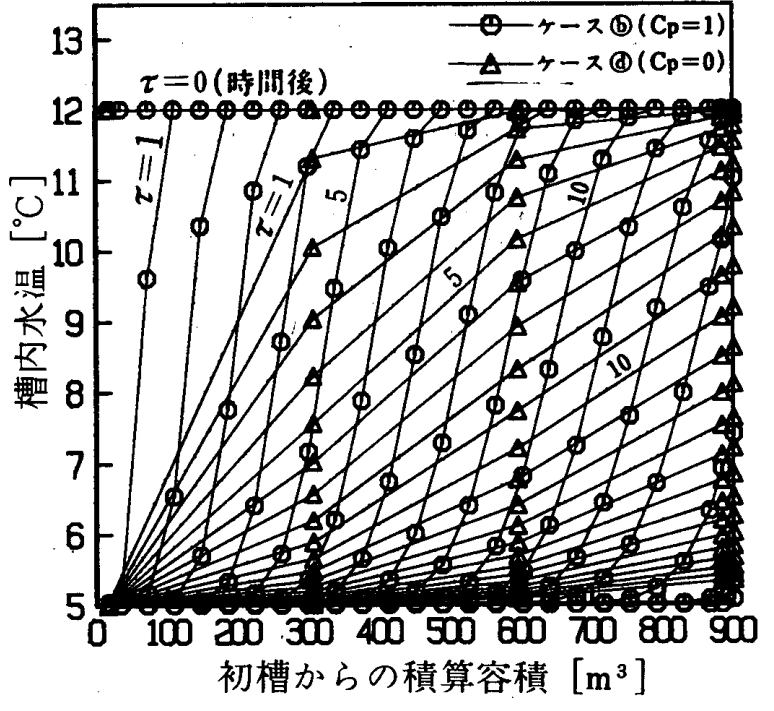

図-17 $C_{P}$ の違いによる槽内水温分布変化

（ケース@）とを選び，(冷房期を想定して）熱源からの 還り温度が一定值 $5^{\circ} \mathrm{C}$ の冷水を初槽へ投入した場合の 一日分の水温分布変化を比較した結果である。この結果 を踏まえ, 前記 6 ケースの各々について, 時分割間隔 $\Delta \tau$ を 0.5 時間として年間にわたるシミュレーションを 実行した。その結果から熱源の製造熱量・稼動時間・機 器別エネルギー消費量等の年間積算值をまとめて表一7 に示す。

\section{1 二次ポンプ動力}

空調機器コイルレベルでの実除去熱量はモデルシステ ム(1), (2)とも冷熱側が $175.9 \sim 176.1 \mathrm{Gcal}$, 温熱側が 203.9〜204.5 Gcal であり，ケース間の差はほとんよ゙な い。二次ポンプ動力消費量についても，各ケース間には ほとんど差が現われていないが，これはいずれのケース も初槽水温が常時熱源からの還水温度に近い值に維持さ れ，コイル入口温度による流量特性の影響の違いが出な かったためと考えられる。

\section{2 一次側機器の稼動時間}

熱源製造熱量はモデルシステム(1)では冷熱側が 186.2 〜 187.0 Gcal, 温熱側が $231.1 \sim 234.9 \mathrm{Gcal}$, モデルシ ステム(2)では，それぞれ 181.0〜181.1 Gcal, 218.0〜 $218.2 \mathrm{Gcal}$ であり, いずれも上記空調機器コイル除去 熱量に対応しており，同一モデルではゲース間の差はほ とんどなかったと言える。熱源（主機）動力は, “混流” は“押流”に対し，モデルシステム(1)が $4.5 \%$ 増，モ デルシステム(2)では $0.7 \%$ 増となってい るが，“押流”と“間流”之の差はほとん ど認められない。熱源動力の差は部分負荷 入力特性によって左右されるが, 部分負荷 運転時間は“混流”が“押流”に対し，モ デルシステム(1)，(2)でそれぞれ $83 \%, 51$ \% 増となっているにもかかわらず，顕著 
表一7 混合流九特性の違いによる比較

\begin{tabular}{|c|c|c|c|c|c|c|}
\hline & \multicolumn{3}{|c|}{ ヒデリシステム(1) } & \multicolumn{3}{|c|}{ 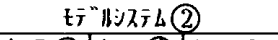 } \\
\hline & \begin{tabular}{l|}
$-\lambda($ (b) \\
"押流"
\end{tabular} & 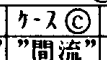 & \begin{tabular}{|l|}
$-x$ (1) \\
"湿流"
\end{tabular} & 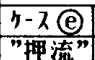 & \begin{tabular}{|l|}
-20 \\
"間流"
\end{tabular} & $\frac{n-7.8)}{" \text { 湿流" }}$ \\
\hline \multirow{3}{*}{ 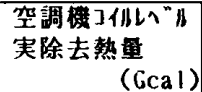 } & 176.0 & 176.0 & 175.9 & 176.0 & 176.1 & 176.0 \\
\hline & 204.5 & 204.5 & 204.5 & 204.2 & & 203.9 \\
\hline & 380.5 & 380.5 & 380.4 & 380.0 & 379.9 & 379 . \\
\hline \multirow{3}{*}{ 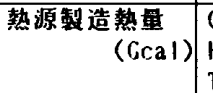 } & 186.7 & 187.0 & 186.2 & 181.1 & 181.1 & 181.0 \\
\hline & 231.1 & 234.9 & 234.2 & 218.2 & & 218.0 \\
\hline & 417.8 & 421.9 & \begin{tabular}{|l|}
420.4 \\
\end{tabular} & 399.3 & 399.2 & 399.0 \\
\hline \multirow{3}{*}{$\begin{array}{l}\text { 熱源運転時間 } \\
(1 \text { 台当 } \eta) \quad(h)\end{array}$} & 658.0 & 599.5 & 1007.5 & 957.0 & 980.5 & 1161. \\
\hline & 633.8 & 695.8 & 996.3 & 987.8 & 1013.8 & 1106 \\
\hline & 1291.8 & 1295.3 & 2003.8 & 1944.8 & 1994.3 & 2268.0 \\
\hline \multirow{3}{*}{ 時間平均製造 } & 283.8 & 311.9 & 184.8 & 189.2 & 184.7 & 155.9 \\
\hline & 364.7 & 337.6 & 235.1 & 220.9 & 15.2 & 197.0 \\
\hline & 323.5 & 325.7 & 209.8 & 205.3 & 200.2 & 175.9 \\
\hline 熱源の全負荷 & 414.9 & 415.6 & 413.8 & 718.5 & 718.6 & 718.4 \\
\hline \multirow{2}{*}{ 相当運転時間 } & 516.3 & 524.8 & 523.2 & 876.1 & 875.9 & 875.3 \\
\hline & 931.2 & 940.4 & 937.0 & 1564.6 & 1594.5 & 1593.8 \\
\hline \multirow{3}{*}{$\begin{array}{l}\text { 墪源の部分負荷 } \\
\text { 運転時間 }\end{array}$} & 344.3 & 301.0 & 880.8 & 399.8 & 441.8 & 720.5 \\
\hline & 175.8 & 269.8 & 783.5 & 203.8 & 247.5 & 431 . \\
\hline & 520.1 & 570.8 & 1664.3 & 603.5 & 689.3 & 1151. \\
\hline \multirow{3}{*}{$R_{f}$} & 0.76 & 0.72 & 0.31 & 0.78 & 0.75 & 0.61 \\
\hline & 0.89 & 0.81 & 0.41 & 0.89 & 0.87 & 0.77 \\
\hline & 0.83 & 0.77 & 0.36 & 0.84 & 0.82 & 0.70 \\
\hline \multirow[t]{2}{*}{$\rho_{p m}$} & 0.29 & 0.39 & 0.33 & 0.40 & 0.41 & 0.38 \\
\hline & 0.33 & 0.34 & 0.40 & 0.45 & 0.44 & 0.46 \\
\hline \multirow{3}{*}{$\sigma_{T}$} & 1.59 & 1.44 & 2.44 & 1.33 & 1.37 & 1.62 \\
\hline & 1.23 & 1.33 & 1.90 & 1.13 & 1.16 & 1.2 \\
\hline & 1.39 & 1.38 & 2.14 & 1.22 & 1.25 & 1. \\
\hline \multirow{3}{*}{$\begin{array}{l}\text { 熱源䞟り動力 } \\
\text { 压縮破 } \\
\text { 空気熱交換器 }\end{array}$} & & & & & & \\
\hline & 112.84 & 113.47 & 118.06 & 106.54 & 106.63 & 107.32 \\
\hline & 22.53 & 22.59 & & 18.84 & 19.32 & \\
\hline \multirow{2}{*}{ 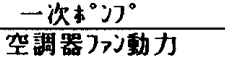 } & 26.03 & 26.19 & 40.40 & 21.01 & 21.55 & 24.51 \\
\hline & 65.01 & 65.01 & 65.01 & 65.01 & 65.01 & 65.01 \\
\hline \multirow{2}{*}{$\begin{array}{l}\text { 云次 } 0^{\circ} \vartheta 7^{\circ} \text { 動力 } \\
\text { 全動力合計 (MWh) }\end{array}$} & 10.57 & 10.57 & 10.58 & 10.59 & 10.61 & 10.67 \\
\hline & 236.98 & 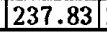 & 68.99 & 21.99 & 223.12 & 229.49 \\
\hline
\end{tabular}

注)C:椧熱, H:温邫, $\mathrm{T}$ :全体を示す

な差が出なかったのは，前述図一10，11 の部分負荷入 力特性の比較的線型に近い部分での運転が多かったため と思われる。一方, 一次ポンプ・補機等熱源回りの動力 消費量は熱源の稼動時間に比例するが, 年間の全運転時 間はモデルシステム(1), (2)とも“押流”が最も小さく, “押 流”, “間流”, “混流” の順に増えている。“混流”は“押流” に対して，モデルシステム(1)では $55 \%$ ，また(2)では 17 \% 増えており，特に分割総数の差が大きいモデルシス テム(1)で顕著に表れている。製造熱量一定のもとでは混 合流れに近いほよ゙，早く部分負荷運転に移行するため， 起動から停止に至る間の部分負荷運転時間の占める割合 が多くなり，全体の運転時間も長くなることが推測され る。ここで，全運転時間の全負荷相当運転時間に対する 倍率を $\sigma_{T}$ とすると， $\sigma_{T}$ は一定の所要製造熱量に対し, 蓄熱システムとしてそれを製造するために必要な熱源運 転時間の大小を示す指標となる。また全負荷相当運転時 間に対する全負荷運転時間の比率を $R_{f}$, 部分負荷運転 時の時間当たり平均製造熱量の全負荷に対する比率を $\rho_{\rho m}$ とすると, 冷熱・温熱別に得られる $\sigma_{T}$ は $R_{f}, \rho_{\rho m}$ に よって次式のように表される。

$$
\sigma_{T}=R_{f}+1 / \rho_{p m} \cdot\left(1-R_{f}\right) \cdots
$$

$R_{f}$ が小さくかつ $\rho_{\rho m}$ が低いほど $\sigma_{T}$ が増すことを示して いる。この $R_{f}$ と $\sigma_{T}$ の関係を $\rho_{\rho m}$ をパラメーターとして

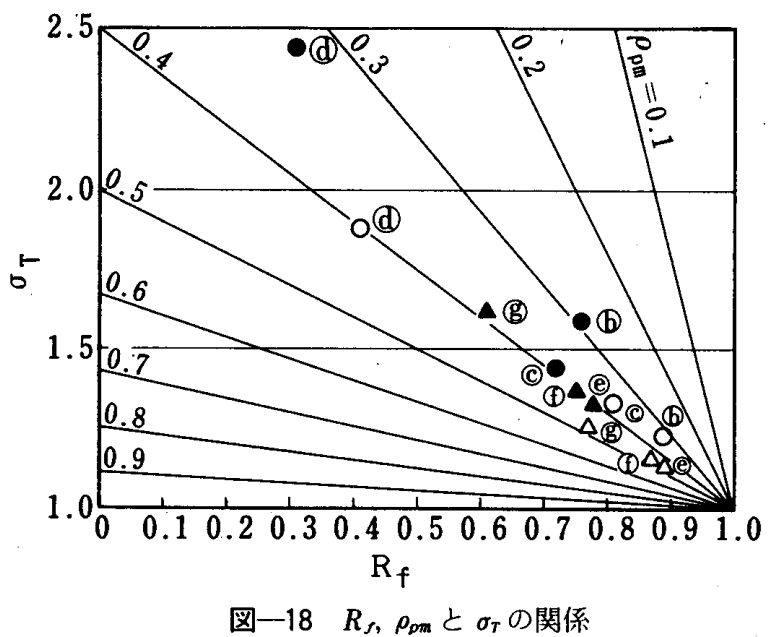

各ケースについて示すと図一18のようになる。冷熱と 温熱側を合わせた $\sigma_{T}$ は，モデル(1)が，“押流”，“間流”， “混流”それぞれ，1.39，1.38，2.14，またモデル(2)では， それぞれ，1.22，1.25，1.42 となっており，両モデル とも, “混流” の值が最も大きく, “混流”では初槽流入 水温の最終槽への影響が比較的早い時点で表れ, 結果と して熱源の稼動時間を增大させると予想した現象を良く 示している。しかし“押流”と“間流”との間についても， モデルシステム(1), (2)ともより䫓著な差が生ずると予想 していたが, わずかの差しか認められない結果となった のは, “押流”, “間流”之も比較的分割槽数が多く, 槽 全体としては完全押しだし流れに近い状態となるため, 個別槽としての混合流れ特性の違いによる影響か減殺さ れたものと考えられる。

\section{3 エネルギー消費}

一次側搬送・補機動力の年間消費量は，モデルシステ ム (1)が，“押流”の 48.6 MWh に対して, “混流”が $75.3 \mathrm{MWh}$ で, 26.8 \% 增え, またモデル(2)の方は, “押 流”の 40.0 MWh に対して, “混流”が $46.5 \mathrm{MWh}$ と なり， $16.7 \%$ 増えている。年間の全電力消費量はモデ ル(1)が，“押流”の $237.0 \mathrm{MWh}$ に対して, “混流”が 269.0 MWh で，(熱源動力として $4.5 \%$, 同補機動力 として 26.8 \% 増え合計で) $13.5 \%$ 増え，またモデル (2)の方は, “押流”の $222.0 \mathrm{MWh}$ に対して，“混流”が $229.5 \mathrm{MWh}$ となり,(熱源動力として $0.7 \%$, 同補機 動力として 16.7 \% 増え合計で) $3.4 \%$ 増えている。

\section{7. 蓄熱槽からの伝熱損失}

蓄熱槽の外周に接する構造壁が図一19 のようになっ ている場合，伝熱損失がぞうなるかを見るために，モデ ルシステム(1)を使って年間のシミュレーションを実行し た（ケース円とする）。外周との伝熱計算には一次元熱 流のレスポンスファクター法によっている。また， 5. で述べたケース@の結果は，蓄熱槽からの伝熱損失が全 くないとした場合に相当するが，それに対して機器举動 ならびにエネルギー消費がどのように変わってくるかに 
ついても比較検討するため， $C_{P}$ の值はゲース@と同じ $<0.5$ とした（押流，間流の中間に相当する）。実行結 果の中から, 熱源製造熱量 - 蓄熱槽加らの伝熱損失量等 の年間值について，ケース(a)前記結果の一部とともに 表一 8 に示す。

\section{1 伝熱損失量}

伝熱損失量の年間積算值は，冷水槽（5－10月）から $34.3 \mathrm{Gcal}$; 温水槽（12〜3 月）からは $40.5 \mathrm{Gcal}$, 併せ

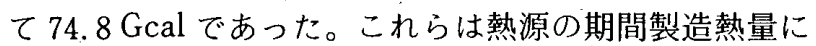
対し，冷熱側が $15.5 \%$ ，温熱側は $14.7 \%$ ，また全体で は $15.1 \%$ に相当する。図一20は製造熱量と伝熱量の月 間値推移であるが, 製造熱量に対する伝熱量の割合は冷 暖房各最盛時の 8 月および 12 月にそれぞれ $9.3 \%$, $11.0 \%$ と最も低く，反対に冷房期の $6 ， 10$ 月には $30 \%$ を超え, 中間期低負荷時での損失が大きいことを示して いる。また， $5 \cdot 10$ 月を除き月間の空調日数に余り差が ない月のみについて見ると, いずれの月も冷熱側より温 熱側の方が大きくなっている。年間を通しての時間当た り平均伝熱量についても冷熱側が $9.35 \mathrm{Mcal} / \mathrm{h}$, 温熱側 が $13.95 \mathrm{Mcal} / \mathrm{h}$ であり，温熱側の方が大きい。これは 蓄熱槽槽内の水温と周囲温度との差が温熱側の方が泠熱

表一8 ゲース@とケースゆの比較

\begin{tabular}{|c|c|c|}
\hline & \multicolumn{2}{|c|}{ 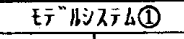 } \\
\hline & $r-x @$ & $\pi-\lambda Q$ \\
\hline \multirow{3}{*}{ 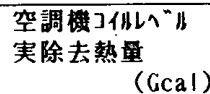 } & 176.0 & \\
\hline & 04.5 & \\
\hline & 380.5 & 380.5 \\
\hline \multirow{3}{*}{$\begin{array}{r}\text { 熱源製造熱量 } \\
\text { (Gcal) }\end{array}$} & 186 & 220 \\
\hline & 234.8 & 275.0 \\
\hline & 421.6 & 495.9 \\
\hline \multirow{3}{*}{$\begin{array}{l}\text { 蓄熱槽伝熱量 } \\
\text { (Gcal） }\end{array}$} & 0.0 & 34.3 \\
\hline & 0.0 & 40.5 \\
\hline & 0.0 & 74.8 \\
\hline \multirow{3}{*}{$\begin{array}{r}\text { 有効蓄熱量 } \\
\text { (Gcal) }\end{array}$} & 186.8 & 186.6 \\
\hline & 234.8 & 234.5 \\
\hline & 421.6 & 421.1 \\
\hline \multirow{3}{*}{ 熱源運転時間 } & 607.0 & 1164.8 \\
\hline & 671.3 & 1192.5 \\
\hline & \begin{tabular}{l|l}
$\mathrm{T}$ & 1278.3 \\
\end{tabular} & 2357.3 \\
\hline \multirow{3}{*}{$\begin{array}{l}\text { 熱源の全負荷 } \\
\text { 相当運転時間 }\end{array}$} & \begin{tabular}{|l|l|}
$\mathrm{C}$ & 415.1 \\
\end{tabular} & 490.9 \\
\hline & 52 & 614.4 \\
\hline & 939.7 & 1105.3 \\
\hline \multirow{3}{*}{$\begin{array}{l}\text { 熱源の部分負荷 } \\
\text { 連転時間 }\end{array}$} & 300.8 & 841.5 \\
\hline & 228 & 720.0 \\
\hline & 529.6 & 1561.5 \\
\hline \multirow{3}{*}{$R_{f}$} & 0.74 & 0.66 \\
\hline & 0.84 & 0.77 \\
\hline & 0.80 & 0.72 \\
\hline \multirow{2}{*}{$\rho_{\mathrm{pm}}$} & 0.36 & 0.20 \\
\hline & 0.36 & 0.20 \\
\hline \multirow{3}{*}{$\sigma_{T}$} & 1.46 & 2.37 \\
\hline & H & 1.94 \\
\hline & $T$ & 2.13 \\
\hline \multicolumn{3}{|l|}{ 熱源廷り動力 } \\
\hline \multirow{3}{*}{ 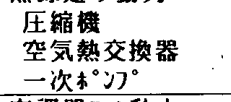 } & 113.32 & 144.28 \\
\hline & 22.29 & 41.11 \\
\hline & 25.82 & 47.55 \\
\hline & 65.01 & 65.01 \\
\hline 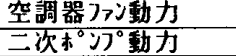 & 10.57 & 10.57 \\
\hline 全動力合計(MWh) & 237.01 & 308.52 \\
\hline $\begin{array}{l}\text { 一次I被”“換算 } \\
\text { 消貫係数 }\end{array}$ & 1.19 & \\
\hline
\end{tabular}

注) $\mathrm{C}$ :椧熱, $H$ :温熱, $\mathrm{T}$ :全体を示す
側に比べ大きいためと

考えられる。にもかか わらず前述の製造熱量 に対する割合の期間值 としては，冷熱側の方 がわずかではあるが増 えているのは, 6,10 月が影響するためであ る $(7 \cdot 8 \cdot 9$ の 3 力月 では $12.7 \%) 。$

7.2 ケース@との 比較

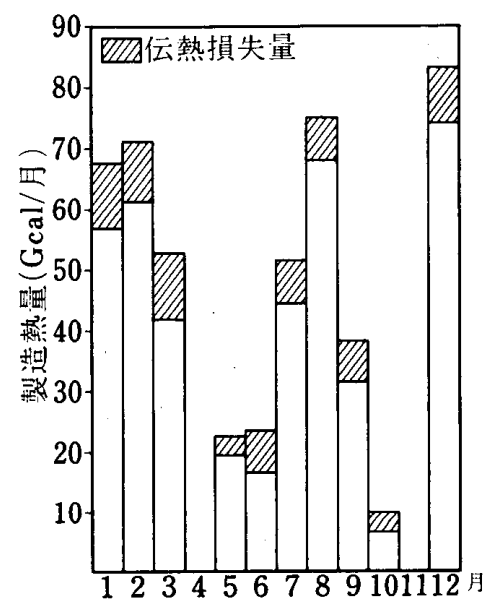

図一20 熱源製造熱量・伝熱損失量の 月間值推移

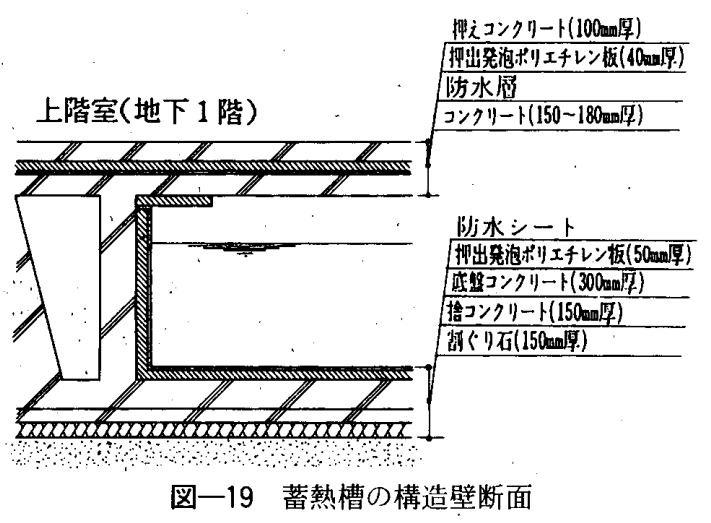

前述のケース@の結果と比較すると，まづ熱源製造熱 量は冷熱側が $18.3 \%$ ，温熱側は $17.1 \%$ ，また全体では $17.6 \%$ 增えている。熱源運転時間については冷熱側が $91.9 \%$, 温熱側は $77.7 \%$, 全体では $84.4 \%$ と大幅に 増えている。 $R_{f}$ は冷熱側が 0.66 (10.8\% 娍), 温熱側 は0.77.(8.3\% 減）と余り減っていないが， $\rho_{\rho m}$ の方は 冷熱・温熱側とも $0.20(44.4 \%$ 減）と大幅に減ってお り，いかに低負荷運転時間が増えたかを示している。低 負荷運転時間が大幅に増えた原因は，休日には，ケース (a)の方は熱源が一旦停止すると, 槽内水が二次側に使用 されないので, 停止時点の温度が維持されるため, 22 時となっても起動しない。しかし，ヶースゆでは夜間運 転の停止後も, 昼間二次側の消費がなくとも, 周井との 伝熱により (最終槽) 水温も変化し, 熱源起動限界温度 に達するため，熱源が起動してしまうことによる。一旦 起動すると，以降伝熱損失分を製造すべく，(わずかの 水温変化であるため）極端な部分負荷運転状態となるに もかかわらず運転が続くことになる。この結果前記ケー ス(a)の熱源圧縮機動力 113.3 MWh に対しても, 27.3 \% 増亡伝熱損失相当の増分率 $17.6 \%$ を超えている。一 次側搬送・補機動力の合計は $84.3 \%$ と増加し, 熱源動 力と併せて全動力消費量は， $30.2 \%$ 増となって現れて いる。槽内平均水温をとらえるあるいは負荷 需要予測等をもとに熱源発停を制御するな ビ，蓄熱式空調システムにおける熱源運転管 理方法の重要性を示唆している。

8. まとめ

本研究により，得られた知見および今後の 検討すべき課題を要約すると以下のようにな る。

1）現実の蓄熱式空調システムについて, (1)システム全体を時間前進差分型の構造の扱 いにより，(2)完全押し出し流れと混合流れ領 域が混在する槽の水温分布を表現でき，(3水 温分布と熱収支との間の整合性を保ちなが ら，長期間にわたってシミュレーションする 方法を示すことができた。 
2）一次エネルギー換算による消費係数他, 蓄熱式空 調システムについての機器エネルギー消費構造を示し た。

3）年間で見ると, 蓄熱槽の水温分布すなわち混合流 れ特性は熱源の圧縮機動力には左程影響しないが, 運転 時間については大きく左右し, 熱源回り補機ならびに一 次ポンプ等搬送エネルギー消費量に影響を及ぼす。また， 蓄熱槽が完全押しだし流れに近いほどエネルギー消費量 もまた，少なくなることを定量的に明らかにした。しか し, 二次側水搬送動力は, 初槽水温が維持されることが 多く，汲み上げ水温一定のため，建物側熱負荷によって のみ左右され，槽の混合流れ特性の影響はほとんど受け ない。

4）蓄熱槽外周との伝熱が，熱源製造熱量に及ぼす影 響を動的計算から定量的に明かにした。また，熱源の製 造熱量の増大のみならず機器の運転時間に対しても影響 を及ぼし，結果として期間エネルギー消費を左右するこ とを定量的に明らかにした。

5) 各単槽の $C_{P}$ の值と槽数を減ずることにより，両 極端の混合流れ特性が想定されるモデルを設定し，エネ ルギー消費へ及ぼす影響の違いを示したが，今後 $C_{P}$ の 值については，実槽における水温変動等の調査から同定 し槽の形状・構成槽数・流量等との関係を明らかにする ことによって, 本研究で提示した手法の実槽への適用性 を確立する必要がある。

\section{9. 謝 辞}

シミュレーション・プログラムの開発を担当され，ま た空調システム設計の面から御助言を頂いた清水建設

（株）技術本部の和田裕夫氏，竹林芳久氏はじめ関係各 位にはここに記して謝意を表したい。

注

1) システム全体にわたるシミュレーション構造が時間前進 型の差分解法をベースとしており，（1），（2）式に示す ごとく差分各時点の蓄熱槽各単槽の水温は, 解析精度上 は，槽内均一 (平均) 水温としてとらえれば十分である。 しかし槽の混合流れ性状の違いは単槽間の水温分布を左 右し, 特に初槽と最終槽の水温は直接機器挙動に影響を 及ぼすことから，2.3では押しだし流れと完全混合流れ の双方が表現可能なモデルによって水温分布を求めてい る。

2) 機器挙動にとって, 得られた修正前の水温分布は重要で あるが, $\Delta t_{w}$ の值は水温に比べ極めて微小のため, 修正 による影響はほとんどないと考える。

3）全単槽或は槽の挙動時間全体を通して, 必ずしも一定值 として限定はしない。

4）単槽への入力温度の時刻変動が時分割間隔（差分）時間 内において十分近似でき，また（11）式の（完全混合流
れの) 微分方程式の解析解が比較的容易に得られ，かつ 当槽の三時点 $(0,0.5 \Delta \tau, \Delta \tau)$ の值から同一形態の近 似式を求め, 一連の同一方法によって次槽以下の出口温 度を, 繰り返し数值解析し得る性質を有する関数として 二次関数を選定した。

5）（4）式の蓄熱槽の水温修正量の年間を通しての累積出現 頻度が，冷水・温水槽併せて計算時点の, $99.6 \%$ が $0.05^{\circ} \mathrm{C}$ 以下に，また $70.0 \%$ が $0.01^{\circ} \mathrm{C}$ 以下の範囲に分 布しており,シミュレーション精度は十分と考える。

\section{参考文献}

1）松平秀雄, 阪倉康男：蓄熱水槽の蓄熱量の解析（1）基 礎理論解析, 空気調和·衛生工学, Vol. 46, No.4, pp. 11 17, 1972. 4

2）中島康孝：蓄熱槽の熱的重みに関する研究（その1）基 礎理論解析，日本建築学会論文報告集 第 199 号， pp. $37 \sim 47,1972.9$

3）中原信生, 相良和伸, 辻本・誠：蓄熱槽に関する研究（第 3 報）運転シミュレーションを用いた実験計画法による 連結完全混合型蓄熱槽の蓄熱槽効率の推定, 空気調和・ 衛生工学会論文集, No. 20, pp. 59 72, 1982.10

4）宮武 修, 田中 学, 窪田誠治：もぐりぜき式蓄熱水槽 の蓄熱効率, 空気調和・衞生工学会論文集, No. 29, pp. $1 \sim 10,1985.10$

5）松平秀雄, 阪倉康男, 宮部喜代二：蓄熱水槽の蓄熱量の 解析（3）蓄熱槽水そうの蓄熱量の解析, 空気調和・衛 生工学, Vol. 47, No. 5, pp. 25 35, 1973.5

6）川井昌裕ほか 3 名：事務所建築における省エネルギー手 法の効果に関する実測調查分析（第 4 報）蓄熱槽の混合 特性に関する夏期実測結果, 空気調和・衛生工学会学術 講演会講演論文集, pp. 245 248, 1980.10

7）櫻井 翰ほか 3 名：空調システム・シミュレーションプ ログラムの開発（第 1 報）プログラム構造と適用例，日 本建築学会大会学術講演梗概集, pp. 795 796, 1982.10

8）川井昌裕ほか 3 名：空調システン・シミュレーションプ ログラムの開発（第 2 報）給気系計算, 日本建築学会大 会学術講演梗概集, pp. 797 798, 1982.10

9) 櫻井 翰ほか 3 名：空調システムシミュレーションプロ グラムの開発（第 6 報）開放回路方式, 空気調和・衛生 工学会学術講演会講演論文集, pp. 585 588，1983.10

10）日本建築学会編: 新建築学体系, 第 27 巻, 設備計画, pp. 278 279, 1982.3

11）空気調和・衛生工学, Vol.59, No.1, 特集 “設備機器の エネルギ効率”, pp. 36, 1985.1

12）矢作和久, 吉井 功：搬送系の省エネルギ, 空気調和・ 衛生工学会論文集, No. 5, pp. 43- 54, 1977.10

13）木村建一：建築設備基礎理論演習, 学献社, 1970.7

14）櫻井 翰ほか 4 名：事務所建築における省エネルギー手 法の効果に関する実測調查分析（第 5 報）蓄熱槽におけ る熱損失, 空気調和・衛生工学会学術講演会講演論文集, pp. $249 \sim 252,1980.10$

15）空気調和・衛生工学会編：蓄熱式空調システム, 空気調 和・衛生工学会, 1982.2 


\section{SYNOPSIS}

UDC : $697.94: 697.328$

\section{EQUIPMENTS BEHAVIOR AND ENERGY CONSUMPTION RELATING TO AIR CONDITIONING SYSTEM INCLUDING A REGENERATIVE WATER VESSEL OF OPEN CIRCUIT TYPE}

by MIKI SAKURAI, Institute of Technology, Shimizu Construcion Co. Ltd., Member of A. I. J.

Mixing flow condition in regenerative water vessel of open circuit type which is included in air conditioning system must give the effect also to energy consumption by equipments of the system. The analytcal method for behavior and energy comsumption of equipments is presented and a simulation program was made. A standard model of air conditioning system including a regenerative water vessel is set and on three cases of the model, in which each combination of perfect mixing flow and piston flow in the vessel is different, equipment behaviour and energy comsumption are simulated by the program. From the results, running time of heat source machine and energy comsumption are compared for the effect by flow condition type. At the same time, the quantitative effect to energy comsumption by heat loss from the vessel is made clear. 